\title{
Interpreting the withdrawal clause of the Treaty on the Non-Proliferation of Nuclear Weapons (NPT): options within the 2010 NPT review cycle
}

\author{
Jenny Nielsen \\ School of Social Sciences \\ Politics and International Relations Division \\ University of Southampton \\ Southampton SO17 1BJ, UK \\ E-mail: nielsen@soton.ac.uk
}

\begin{abstract}
The actions of the Democratic People's Republic of Korea (DPRK) in 2003, resulting in the first case of a state party exercising its sovereign right to withdraw from the Treaty on the Non-Proliferation of Nuclear Weapons (NPT) and its subsequent test of an explosive nuclear device in October 2006, have prioritised the need for a consolidated clarification of the duties, responsibilities, procedures and consequences associated with implementing Article X.1 of the NPT. Given the existing broad support for such a clarified interpretation amongst NPT state parties, the 2010 NPT review cycle presents an opportune juncture to provide such a consolidation of the Treaty's withdrawal provision.
\end{abstract}

Keywords: Treaty on the Non-Proliferation of Nuclear Weapons; NPT; withdrawal clause; peremptory norm; NPT review process; Article X.1; interpretation of multilateral treaties; 2010 NPT Review Conference; 2007 NPT PrepCom; subsequent agreement; Vienna Convention on the Law of Treaties.

Reference to this paper should be made as follows: Nielsen, J. (2008) 'Interpreting the withdrawal clause of the Treaty on the Non-Proliferation of Nuclear Weapons (NPT): options within the 2010 NPT review cycle', Int. J. Nuclear Law, Vol. 2, No. 2, pp.109-114.

Biographical notes: Jenny Nielsen is a PhD student in the Division of Politics and International Relations at the University of Southampton (UK), researching US nuclear non-proliferation policy vis-à-vis Iran. She also assists on research projects relating to the Treaty on the Non-Proliferation of Nuclear Weapons (NPT) and its review process at the Mountbatten Centre for International Studies (MCIS), University of Southampton.

\section{Introduction}

During the first of three scheduled sessions of the Preparatory Committee (PrepCom) for the 2010 NPT Review Conference, which was held in Vienna during 30 April-11 May 2007 , states parties of the treaty revisited previous discussions from the 2005 NPT review cycle in an attempt to establish a common and explicit understanding of what specifically the withdrawal clause of the 1968 treaty entails in contemporary and future practice. 
Commonly heralded as the 'cornerstone of the nuclear non-proliferation regime', the Treaty on the Non-Proliferation of Nuclear Weapons (NPT), arguably remains the normative and legal basis of the regime that ultimately seeks to prevent further states from acquiring a nuclear weapons capability. With its near universality, with the exception of four states, ${ }^{1}$ the NPT remains the WMD-prohibitive treaty with the greatest adherence. The negotiators of the NPT included a specific withdrawal clause in respect of the sovereign right of states in relation to international legal agreements (Shaker, 1980). This withdrawal clause of the NPT is comprised in Article X.1 of the treaty and states as follows:

\begin{abstract}
"Each Party shall in exercising its national sovereignty have the right to withdraw from the Treaty if it decides that extraordinary events, related to the subject matter of this Treaty, have jeopardized the supreme interests of its country. It shall give notice of such withdrawal to all other Parties to the Treaty and to the United Nations Security Council three months in advance. Such notice shall include a statement of the extraordinary events it regards as having jeopardized its supreme interests."
\end{abstract}

The relatively ambiguous wording of the withdrawal clause which was drafted four decades ago, during a largely bi-polar security environment and whilst support for the eventual treaty was at best uncertain, presents states with the perceived need to consolidate and agree on a common explicit understanding of what Article X.1 in actuality means in the contemporary political and security milieu. The urgency of this perceived need has been precipitated by the precedent set by the Democratic People's Republic of Korea (DPRK) exercising its notice to withdraw from the NPT in January $2003 .^{3}$ Of particular concern is the precedent set by the relatively inconsequential response from the international community to the DPRK's withdrawal, particularly given the subsequent North Korean nuclear activities including a nuclear explosive test on 9 October 2006. The response by the international community to the DPRK's withdrawal of the NPT until this critical event was arguably weak, at best, and more worryingly, at worst, potentially indirectly encouraging to any state contemplating the consequences of a future withdrawal from the treaty.

Aware of the implications of the mild international response to the North Korean case prior to October 2006, states parties at the 2007 NPT PrepCom revisited and reiterated support for the discussions of clarifying the process for the implementation and consequences of the withdrawal clause which was previously proposed during the latter part of 2005 NPT review cycle. ${ }^{4}$ Working papers and statements presented by states parties to the 2007 NPT PrepCom convey a broad support and consensus for a establishing a common understanding of the responsibilities of a state party wishing to exercise its sovereign right to withdraw from the treaty, as well as the responsibilities of the international community to address the act appropriately, namely through a commensurate response by the United Nations Security Council (UNSC).

\title{
2 The 2007 NPT PrepCom addresses Article X.1
}

Other than the three main cluster discussions relating to the three pillars of the treaty, NPT withdrawal was one issue that received special attention at the 2007 NPT PrepCom, with 'special time' allocated on the agenda for its discussion on the morning meeting of the last day of the session. Given limited time for states parties to present substantive 
discussion to the PrepCom, as a result of the agenda not being formally agreed until the second week of the session due to strategic procedural manoeuvring by the Iranian delegation, many state parties furthermore consolidated their proposals in the form of official working papers of the 2007 NPT PrepCom. Australia, Canada, the European Union (EU), the USA submitted working papers detailing proposals relating to a clarification of the interpretation of the withdrawal clause. ${ }^{5}$

An examination of the statements and working papers exposes broad consensus on the clarifying the interpretation of the withdrawal clause, particularly in regards to the responsibilities of a state party wishing to exercise its sovereign right of withdrawal and the duty of the international community to respond in a commensurate and timely manner to such an event. Specific common objectives are apparent from the statements and documents presented to the 2007 NPT PrepCom by states parties. These converging objectives include a consolidation and understanding that:

- $\quad$ accountability for treaty violations will not be absolved through the act of withdrawal

- benefits (in the form of materials, technology and equipment) attained through the guise of peaceful uses from cooperation under the NPT remain pledged for peaceful purposes under IAEA safeguards, and should be dismantled or returned in the event of withdrawal

- following a notification of withdrawal, the UNSC should address the event in a immediate, consistent, and commensurate manner.

Convergence on these objectives is sought in order to strengthen the credibility of the non-proliferation regime which is legally underpinned by the NPT and in order to act as a disincentive for any states parties who may potentially consider exercising their sovereign withdrawal right.

\section{Three options for Article X.1 clarification in the 2010 NPT review cycle}

Three conceivable options within the 2010 NPT review process cycle exist for consolidating a clarification of the withdrawal provision contained in Article X.1 of the NPT. The first option for this purpose would consist of including a paragraph in the Final Document of the 2010 NPT Review Conference containing the consolidated agreed interpretation of the responsibilities, duties and procedures associated with a state's sovereign right to withdraw from the NPT, applicable to the state intending to exercise withdrawal, as well as the international community including the UNSC, the IAEA, and states parties. The inclusion of a consolidated interpretation of Article X.1 in the Final Document of the 2010 NPT Review Conference could constitute a significant step in the establishment of a 'peremptory norm of international law' relating to the withdrawal provision of the NPT. As defined in Article 53 of the Vienna Convention of the Law of Treaties (1969), "a peremptory norm of general international law is a norm accepted and recognized by the international community of States as a whole as a norm from which no derogation is permitted and which can be modified only by a subsequent norm of general international law having the same character". 6 In this manner, a consolidated 
understanding of the duties, responsibilities, and procedures associated with a state's notification of withdrawal from the Treaty, will minimise/remove potential ambiguity from the text of Article X.1 of the NPT.

Arguably, two issues exist with this first option of including the consolidated clarification of Article X.1 in the Final Document of the NPT 2010 Review Conference. The first issue, is that such an inclusion is only possible if the NPT states parties at the 2010 NPT Review Conference are able to reach consensus on and adopt a Final Document. Since the NPT's entry into force in 1970 , only three ${ }^{7}$ of the past seven NPT Review Conferences have achieved consensus to produce Final Documents. ${ }^{8}$ The second issue, is that the legal status of any declaration contained in the Final Document of an NPT Review Conference is arguably open to interpretation and contestable. To give one example, according to contemporary US State Department interpretation, the Final Documents of NPT Review Conferences are regarded as "statements of political consensus at a particular point in time upon certain policy positions. They do not themselves have any legal import, and so of course they would not constitute a 'subsequent agreement between the parties regarding the interpretation of the treaty or the application of its provisions' within the meaning of Article 31(3) of the Vienna Convention on the Law of Treaties".

Therefore, according to the contemporary US State Department stance on the validity and legal status of NPT Final Documents, such documents are not legally binding. Hence, if such a perception is adopted by state parties, Final Documents of NPT Review Conferences can be disregarded when they no longer suit policy $d u$ jour if they are considered to be mere political declarations. However, if an agreed and commonly held norm of the practices and expectations associated with the sovereign right of states to withdraw from the NPT exists, then it could be argued that such an established norm of international law will be valid irrespective of the Final Document's political relevance at any point in the future.

The second option within the NPT review process would be for all parties of the NPT to draft and reach an explicit subsequent agreement on the interpretation of the application of Article X.1, and either, annex it to the Final Document of the 2010 NPT Review Conference, or include it as a special jointly submitted Working Paper to the 2010 NPT Review Conference. In either form, the agreed clarification of the withdrawal clause should be explicitly drafted to indicate that states parties wish to submit this document as a jointly agreed clarification complementary to Article X.1 of the NPT. Pursuant to Article 31.3 (a) of the Vienna Convention on the Law of Treaties (1969), in interpreting a treaty, 'any subsequent agreement between the parties regarding the interpretation of the treaty or the application of its provision', 'shall be taken into account, together with the context' ${ }^{10}$ If the clarification of responsibilities, duties, and procedures associated with exercising to withdraw from the NPT were to be adopted as an explicit subsequent agreement between the parties of the NPT, complementary and in relation to Article X.1, rather than included as a paragraph of the Final Document of the 2010 NPT Review Conference, the validity of the agreement could be less contestable. As with the first option, annexing such a subsequent agreement to the Final Document would require the adoption of a Final Document, whereas the submission of a joint Working Paper could be executed without this condition.

A third option for consolidating the interpretation of the NPT's withdrawal provision is to reach a subsequent agreement on the interpretation of Article X.1 of the NPT in a multilateral forum outside the NPT review process. Possible forms this subsequent 
agreement could be pursued as include as a First Committee UN Resolution or as a Resolution in the Conference of Disarmament (CD) sessions. The advantage of pursuing the adoption of such a subsequent agreement to the NPT outside of the NPT review process is to circumvent the requirement of the adoption of a Final Document and although the agreement would make explicit reference to an agreed clarification of the withdrawal provision from NPT review process discussions, it would avoid potentially interfering with or monopolising the NPT review process sessions covering all provisions of the Treaty, not solely Article X.1. The technicalities of adequate representation of NPT states parties within forums outside the NPT review process would have to be taken into account.

\section{Conclusion: implications for the NPT review process}

In order to consolidate a clarification on the withdrawal provision at the 2010 NPT Review Conference, states parties could seize the existing momentum on clarifying the withdrawal provision contained in Article X.1 of the NPT and utilise the groundwork inherited from the 2005 NPT review cycle and carried forward into the 2007 NPT PrepCom. If such a clarification of the withdrawal provision is reached by consensus in the form of a 'subsequent agreement' (to the NPT) and annexed to the Final Document of the 2010 NPT Review Conference, it would be legally binding and could set a precedent for future efforts to consolidate contemporary interpretations of other NPT provisions. The establishment of such a precedent could be seen to serve as a procedural method based to bolster credibility and allay existing criticisms of the role of the NPT review process and the multilateral arms control machinery. Such action would also bypass the existing divergence in interpretations of NPT review process Final Documents. Potentially, political will permitting, other NPT issues which could gain common ground of consensus in the future, could eventually also be consolidated as subsequent agreements, including perhaps establishing a new safeguards standard to include the Additional Protocol (INFIRC/540).

\section{Acknowledgements}

The views expressed in this paper are the sole responsibility of the author and do not necessarily reflect the views or opinions of MCIS or the University of Southampton.

\section{Reference}

Shaker, M.I. (1980) The Nuclear Non-Proliferation Treaty: Origin and Implementation 1959-1979, London: Oceana Publications, Vol. 2. 


\section{Notes}

1 India, Israel and Pakistan have never signed the NPT. The DPRK announced its intent to withdraw from the NPT on 10 January 2003 with immediate effect.

2 Treaty on the Non-Proliferation of Nuclear Weapons, 1968, Article X.1.

3 Text of North Korea's Statement on NPT Withdrawal, 10 January 2003, http://www .kcna.co.jp/item/2003/200301/news01/11.htm.

4 Such proposals in the 2004 NPT PrepCom include working papers submitted by Germany and France. See, Strengthening the NPT against withdrawal and non-compliance: Suggestions for the establishment of procedures and mechanisms, Working Paper submitted by Germany, NPT/CONF.2005/PC.III/WP.15, and Strengthening the nuclear non-proliferation regime, Working paper submitted by France, NPT/CONF.2005/PC.III/WP.22. Furthermore, similar proposals were submitted by the European Union, Australia and New Zealand to the 2005 NPT Review Conference. See, Withdrawal from the Treaty on the Non-Proliferation of Nuclear Weapons, European Union common approach: Working Paper submitted by Luxembourg on behalf of the European Union, NPT/CONF.2005/WP.32, and Working paper on article X (NPT withdrawal) submitted by Australia and New Zealand, NPT/CONF.2005/WP.16.

5 Proposals submitted to the 2007 NPT PrepCom include: NPT/CONF.2010/PC.I/WP.22, Article $X$ of the Treaty on the Non-Proliferation of Nuclear Weapons: deterring and responding to withdrawal by Treaty violators - Working paper submitted by the United States of America; NPT/CONF.2010/PC.I/WP.34, Perspectives on issues related to article X of the Treaty on the Non-Proliferation of Nuclear Weapons - Working paper submitted by Australia; NPT/CONF.2010/PC.I/WP.25, Withdrawal from the Treaty on the Non-Proliferation of Nuclear Weapons: European Union common approach - Working paper submitted by the European Union; NPT/CONF.2010/PC.I/WP.42, Other provisions: institutional reform, article $X$ and withdrawal - Working paper submitted by Canada.

6 Vienna Convention of the Law of Treaties (1969), Section 2, Article 53.

7 Final Documents were agreed in NPT Review Conferences in 1975, 1985, 2000.

8 NPT Review Conferences are held every five years. In each of the three years prior to the Review Conference within the NPT review process cycle, there is a NPT Preparatory Committee (PrepCom) session for the upcoming NPT Review Conference.

9 The NPT Review Process and the Future of the Nuclear Nonproliferation Regime, Dr. Christopher A. Ford, US Special Representative for Nuclear Nonproliferation, Remarks to the NPT Japan Seminar - NPT on Trial: 'How should we respond to the challenges of maintaining and strengthening the treaty regime'?, Vienna, Austria, 6 February 2007, $\mathrm{http} / / / \mathrm{www}$. state.gov/t/isn/rls/rm/80156.htm.

10 Vienna Convention on the Law of Treaties, Section 3, Interpretation of Treaties, Article 31, General rule of interpretation, 2, (a). 